\title{
2.0 Country Branding
}

\author{
T. S. Mittilä* \\ Pori Unit \\ Turku School of Economics at the University \\ of Turku \\ Pori, Finland \\ tuula.mittila@utu.fi \\ *Corresponding author
}

\author{
H. L.M. Laurén \\ Futures Research Center \\ Turku School of Economics at the University of Turku \\ Turku, Finland \\ hlmlau@utu.fi
}

\begin{abstract}
The article lays a theoretical ground for empirical futures research on country branding. The concept of crowd branding is introduced.
\end{abstract}

Keywords-brand; futures research; country branding; crowdbranding; place branding

\section{INTRODUCTION}

"Globalization is turning the world into a gigantic supermarket where countries compete to stimulate exports, attract tourism, foreign direct investments, and immigration" [ $[1$, p. 234]. The market place for ideas, culture, and reputation - in addition to products, services and funds - are fusing into a single global community [2].

"Among the conditions that make place branding a necessity is the growing power of international media, the falling cost of international travel, rising consumer spending power, the threat of place parity, a scarce pool of international investors, competition for skilled and professional immigrants and growing consumer demand for a diverse cultural diet stimulated by low-cost global communication media" [3, p. 63].

Governments are, to a greater extent, turning to branding techniques to differentiate their country on the global stage in order to establish a competitive edge over rival countries. They believe that a strong country brand can contribute to the country's sustainable development [4] [5]. A strong country brand may also restore flawed international credibility, increase international political influence, and stimulate stronger international partnerships [6].

Branding a country is the building of positive associations for itself, its inhabitants and products. The ultimate superior goal of the country brand is to contribute to the welfare of its citizens. Governments should create, promote, protect, and supervise a country's brand [7] [8]. Country branding is a complex and controversial phenomenon [9]. It is complex because it encompasses multiple levels, dimensions, and disciplines beyond conventional branding, and as a highly politicized activity that generates conflicting viewpoints and opinions; it can be controversial as well.

In the new economy, there is a trend for co-operative arrangements including different sectors of society, such as central and local government, regulatory bodies and citizens, interest groups as well as private sector firms. Networks are developed with intermediary bodies, which include trade associations, research and technology organizations, local and central government institutions and citizens' interest groups. Social networks of interpersonal ties add to the more formal inter-organizational relationships that constitute policy networks. In social networks, relations (ties) can be single or multiple and may also differ in terms of direction, content, intensity and strength. They do not automatically indicate likemindedness or trust. Boundaries can be defined by the analyst's view of which groups are involved, or by including only those people that are actually related to each other somehow [10]. In country branding, individual citizens play a central role in the construction of brand identity and, in turn, their networks may affect the brand identity as well. Various roles of the one person [11] make this individual level fuzzy. People involved may have the roles of a political decision maker or an official in the public sector simultaneously.

The role of information technology and social media in interpersonal communication has increased in last decades. "Social Media is a group of Internet-based applications that build on the ideological and technological foundations of Web 2.0, and that allow the creation and exchange of User Generated Content" [12]. There is no systematic way in which different social media applications can be categorized. Also, new sites appear in cyberspace every day. However, most people would probably agree that, e.g., Wikipedia, YouTube, Facebook, and Second Life are all part of this large group. Social media has a tremendous impact on online environment and online communication. One could even argue that on a larger scale it has altered the whole world of communication and information. [13].

In 2010, the delegation of the Finnish country brand published its report. In building the brand 2008-2010, the delegation collected information, discussed with both domestic and foreign professionals and specialists, engaged Finnish citizens in events and seminars by activities in the media and by internet services, and especially by personal discussions. The delegation defined the brand identity, i.e., the image to strive for, of Finland as a" country that solves the problems". The most essential themes of the brand identity are linked with functionality, education, and nature and environment. The vision for Finland in 2030 was presented in the report The acceptance of the report was not favourable and comments and feedback in the social media were fairly negative.

The purpose of this paper is to lay the theoretical ground for a series of empirical studies of the future and online communication in branding Finland and other countries. We are especially interested in the crowdbranding of a country. The methodology of the paper was a purposeful literature review of 
place branding and futures research. In this paper, we first discuss the concept and dimensions of a country brand as well as country branding. Thereafter, we scrutinize the process of building and developing the brand identity of a place before discussing the futures of a country brand and researching the futures. Finally, we draw conclusions and present directions for further studies.

\section{CONCEPT OF A COUNTRY BRAND}

In the last decades an increasing number of academics [7] [14] [15] [16] [17] [18] and practitioners [19] has focused on country brand research. References [7] [20] were among the first to discuss country branding. However, there is still no common definition of a country brand. Reference [1, p.8] defines it as “a country's whole image, covering political, economic, historical and cultural dimensions. The concept is at the national level, multidimensional and context dependent". Also social and environmental aspects have been attached to a country's image [18]. A country image can be understood as "the sum of beliefs and impressions people hold about places. Images represent a simplification of a large number of associations and pieces of information connected with a place". $[14$, p. 251] Reference [9, p. 15] defines a country brand as "the unique, multi-dimensional blend of elements that provide the nation with culturally grounded differentiation and relevance for all of its target audiences". A country brand should "attract the 'right' kinds of investment, tourism, trade, and talent" [17, p. 42]. "A country brand belongs to the public domain; it is complex and includes multiple levels, components, and disciplines. It entails the collective involvement of the many stakeholders it must appeal to". [18, p. 467]

There is a significant variation in the application of place brand terms 'country' and 'nation' in relation to countries in the terminology use in place branding [3]. Although defined as a country, reference to 'nation' brands may also incorporate country 'outputs' encompassing the various brand dimensions discussed in the literature, such as culture including gastronomy, sports, film, literature and music, industry, agriculture, heritage and both leisure and business tourism [21]. Reference [14] identified such elements of a country's image as geography, history, proclamations, art and music, famous citizens and other features. A place branding hexagon [22] introduced on the website www.placebrands.net distinguishes such elements as tourism, export brands, foreign and domestic policy, investment and immigration, culture and heritage, and people.

\section{COUNTRY BRANDING - A SUB CATEGORY OF PLACE BRANDING}

There are four main marketing fields which relate to and underpin country branding: country of origin [23] [24] [25] [26], destination branding [27] [28], country image or countryproduct image [29] [30] [31] [32] [33]), and country identity [34] [35] [36]. However, over the years it became evident that country branding is much broader than traditional marketing and branding and involves other disciplines such as international relations and public diplomacy [36].

"Branding a place is, at least in principle, quite simple. A place-brand strategy is a plan for defining the most realistic, most competitive and most compelling strategic vision for the country, region or city; this vision then has to be fulfilled and communicated" [22]. Better strategies recognize that the principal resource of most places, as well as a primary determinant of their "brand essence", is as much the people who live there as the things which are made and done in the place. Therefore, it is fundamental to ensure that the vision of the place is supported, reinforced and enriched by everybody's act of communication with the rest of the world. This coherence of communication is necessary because every place has to compete with every other place for share of mind, share of income, share of talent and share of voice in the globalized world.

\section{BUILDING COUNTRY BRAND IDENTITY}

Governments should create, promote, protect, and supervise a country's brand [7] [8] because governments are at the center of country branding [36]. Place branding - country branding in this case - means bringing added attraction to a place, the central issue being to build the brand identity [37].

A simple and clear explanation of brand identity underscores the significance of the supply side on the brand concept [38]. In a fundamental sense, brand identity represents what the organization wants the brand to stand for [39]. Therefore, the creation of an appropriate brand identity for a place and subsequent image-building is regarded as an important element of place marketing [40] [41] [42].

Reference [43] emphasizes the supply-centric perspective of brand identity. In city branding, if the process is to be successful, the key stakeholder organizations must come together in partnership. This does not refer to the usual publicprivate partnership or a committee of wise men and women, but to a formal or informal body with clearly stated terms of reference and a program with deadlines and deliverables. The key stakeholders jointly develop, create and implement the brand in the spirit of shared responsibility. Accordingly, "creating such a partnership is the first step in changing the way the city operates, because it simultaneously crosses divides such as those between town and gown, government and business, arts, leisure and sports, commerce and culture, and the public, private and voluntary sectors" [44, p. 41].

Stakeholders should be engaged in the whole branding process and "not treated like participants in a focus group" [45]. In the context of constructing a country identity, the internal brand image of citizens and residents highly impact the brand identity of a country. Therefore, interaction and communication with them via social media in the construction of the country's identity is crucial. Stakeholders can realize the place brand through their actions, investments, decisions, and communications.

During the process of constructing a brand identity, members have to decide how a country will look like in the future, what kind of value it will offer to stakeholders, how other people will experience that, and what they can jointly do to make their vision a reality. "This requires willingness to come together and work through these challenges even when that may be difficult through conflicts of interest, different opinions, differing timescales and sometimes even personal dislikes" [44, p.41]. The conflict of interests stems from the 
fact that the city - or another place - simultaneously is a place of residence and a place of work, a tourist destination, and a place of opportunity for people who invest in it [46]. Places do not have single, unique "identities", but instead they are full of internal differences and conflicts [47]. Despite the differences in place "identities", places aim at building a unified brand identity for marketing purposes.

\section{CROWDBRANDING}

Crowdsourcing is an online, distributed problem-solving and production model that has emerged in recent years. "Simply defined, crowdsourcing represents the act of a company or institution taking a function once performed by employees and outsourcing it to an undefined (and generally large) network of people in the form of an open call. This can take the form of peer-production (when the job is performed collaboratively), but is also often undertaken by sole individuals. The crucial prerequisite is the use of the open call format and the large network of potential laborers". [48, p.5] Reference [49] studied crowdsourcing in the private sector. They define crowdsourcing as "the use of large groups of individuals to perform tasks commonly performed by employees or designated agents". The results of the study reveal four common uses of the crowd. These are marketing/branding, productivity, product/service innovation and knowledge capture. Each identified use links to a specific organizational need with specific desired outcome.

In our literature review, we could not find any scholarly paper discussing the issue of crowdsourcing in branding. However, in the practical context of product branding, the term 'crowd branding' is introduced meaning that people engage and interact with the brand and the share their encounters with friends [50]. We adopt the concept of 'crowdbranding' and define it as the use of large groups of individuals in constructing and communicating the brand identity and brand image.

\section{FUTURES RESEARCH ON COUNTRY BRANDING}

Both spatial and temporal dimensions are the key concepts in the modern futures research. The Limits to Growth report to the Club of Rome [51] clearly and visually indicates that there is a human perspective in time and space. The closer the issue of concern is located in time and space, the more important it is to us humans. Based on this approach a chosen time frame can become a strategic long-term dimension when the forwardlooking methods are utilized for decision-making and planning. It can therefore be stated for modern futures research that short term considerations range from the present to five years, the medium term from five to ten or alternatively 20 years, and the long term from twenty to fifty years [52]. The temporal dimensions in futures research are closely related to the geographical area. Reference [52, p. 32] suggests that the broader the horizons for futures, the further we need to extend our inquiries forward. In the case of the chosen example of Finland's country brand the target year of the vision was 2030, i.e., 20 years from the publishing year of the brand identity report for the country.

Taken into consideration the complexity and multidisciplinarity of any research problem in the futures research field, there are several methods and options how to study the country branding in the forthcoming years. Another aspect important to point out in the methodology is that the individuals engaged in the process are invited to act proactively. This can be performed in sharing their own views and supporting those of the other stakeholders during the process. Often the bottom-up involvement in any society can generally be linked to the emerging methods using social media, such as crowdsourcing. In this article the terminology is theoretically developed further, and the authors coined the concept of 'crowdbranding' for this purpose.

Futures research methods can be categorized and benefitted in various ways as well as in multiple ways combined in a sequential process over time. For the branding questions at hand, the future empirical studies will most probably explore the forward-looking views of individuals, experts and other stakeholder representatives. The interactive futures research methods may include special modifications made for this study such as open access panels, iterative Delphi rounds, as well as scenario processes and scenario building or backcasting (cf. [53]).

\section{CONCLUSIONS AND IMPULSES FOR FURTHER RESEARCH}

The paper contributes to theoretical discussions in many ways. First, we bring together research on place branding and the methodology of futures research. Second, we introduce the concept of 'crowdbranding' to illustrate crowdsourcing in the context of country branding as well as other place branding. Third, this article presents the novel combination of traditional ways of studying competitiveness and attractiveness of a "locality" and to add the futures research methods and forwardlooking strategic thinking to it.

Selected futures research methods are presented in a concise manner in this first article of a series of writings concentrating on the issues of branding in relation to a place, a country or space as institutional approaches. At the end, the target of the authors is to combine the points of view of the traditional from top-down multi-disciplinary methods to those newly developed in the early years of the third Millennia such as the crowdbranding and finally aim to liaise with these two contrasting approaches.

\section{REFERENCES}

[1] S. Anholt "Editor's Foreword," Journal of Brand Management, vol. 9 (45), April 2002, pp. 229-239.

[2] S. Anholt "Editorial: Some important distinctions in place branding," Place Branding, vol.1 (2), 2005, pp. 116-121.

[3] S. Hanna and J. Rowley "An analysis of terminology use in place branding," Place Branding and Public Diplomacy, vol.4 (1), 2008, pp. $61-75$.

[4] E. Jaffe and D. Nebenzahl, National Image and Competitive Advantage: The Theory and Practice of Country-of-Origin Effect, Copenhagen: Copenhagen Business School Press, 2001.

[5] I. Kleppe and L. Mossberg "Company versus country branding: 'same, same but different'," in Primary Industries Facing Global Markets: The Supply Chains and Markets for Norwegian Food and Forest Products F. Asche, Ed. Copenhagen: Copenhagen Business School Press, 2006, pp. 217-246.

[6] J. Yan "Ethical imperatives in nation branding: smaller nations enter the global dialogue through nation branding," in Nation Branding: Concepts, Issues, Practice. K. Dinnie, Ed. Oxford: Butterworth Heinemann Dutton, 2008, pp. 170-179. 
[7] P. Kotler, D.H. Haider and I. Rein, Marketing Places: Attracting Investment, Industry, and Tourism to Cities, States, and Nations. New York: The Free Press, 1993.

[8] G. Rawson "Perceptions of the United States of America: exploring the political brand of a nation," Place Branding and Public Diplomacy, vol. 3 (3), 2007, pp. 213-221.

[9] K. Dinnie, Nation Branding - Concepts, Issues, Practice, Oxford: Butterworth Heinemann, 2008.

[10] M. Diani "Introduction: Social movements, contentious actions, and social networks: From metaphor to substance," in Social movements and networks: relational approaches to collective action. M. Diani and D. McAdam, Eds. Oxford: Oxford University Press, 2003, pp. 1-18.

[11] E. Gummesson, Many-to-Many Marketing: Från one-to-one till manyto-many i nätverksekonomins marknadsföring, Malmö: Liber Ekonomi, 2004

[12] A.Kaplan and M. Haenlein "Users of the world, unite! The challenges and opportunities of Social Media," Business Horizons, vol. 53, 2010 , pp. 59-68.

[13] G. Shao "Understanding the appeal of user-generated media: a uses and gratification perspective," Internet Research, vol. 19 (1), 2009, pp. 7-25.

[14] P. Kotler and D. Gertner "Country as a brand, product, and beyond. A place marketing and brand management perspective," Journal of Brand Management, vol. 9 (4-5), 2002, pp. 249-261.

[15] D. Caldwell and J. Freire "The differences between branding a country, a region and a city: applying the brand box model," Journal of Brand Management, vol. 12 (1), 2004, pp. 50-61.

[16] Y. Fan "Nation branding: what is being branded?" Journal of Vacation Marketing, vol. 12 (1), 2006, pp. 5-14.

[17] M. Aronczyk “'Living the brand': nationality, globality and the identity strategies of nation branding consultants," International Journal of Communication, vol. 2, 2008, pp. 41-65.

[18] M. Fetscherin "The determinants and measurement of a country brand: the country brand strength index," International Marketing Review, vol. 27 (4), 2010, pp. 466-479.

[19] S. Anholt "Nation-brands of the twenty-first century," Journal of Brand Management, vol. 5 (6), 1998, pp. 395-406.

[20] P. Kotler, S. Jatusripitak and S. Maesincee, The Marketing of Nations: A Strategic Approach to Building National Wealth. New York: The Free Press, 1997.

[21] N. Papadopoulos and L.A. Heslop "Country equity and country branding problems and prospects," Journal of Brand Management, vol. 9 (4-5), 2002, pp. 294-314.

[22] S. Anholt "Branding Places and Nations," in Brands and Branding, R. Clifton and J. Simons, Eds., London: Profile Books Ltd, 2004, pp. 213 226.

[23] M.S.,Roth and J.B. Romeo "Matching product category and country image perceptions: a framework for managing country-of-origin effects," Journal of International Business Studies, vol. 23 (3), 1992, pp. 477-497.

[24] R. Parameswaran and R.M. Pisharodi, R.M. "Confirmatory factor analysis of a country-of-origin scale: initial results," Advances in Consumer Research, vol. 19, 1992, pp. 706-714.

[25] T.A. Shimp, S. Saeed, and T.J. Madden "Countries and their products: a cognitive structure perspective," Journal of the Academy of Marketing Science, vol. 21 (4), 1993, pp. 323-330.

[26] I.D. Nebenzahl and E.D. Jaffe "Measuring the joint effect of brand and country image in consumer evaluation of global products," International Marketing Review, vol. 13 (4), 1996, pp. 5-22.

[27] A. Pritchard and N. Morgan " "Mood Marketing" — The new destination branding strategy: A case study of "Wales", the Brand'," Journal of Vacation Marketing, vol. 4 (3), 1998, pp. 215-229.

[28] G. Hankinson "The management of destination brands: five guiding principles based on recent developments in corporate branding theory," Journal of Brand management, vol. 14 (3), 2007, pp. 240-254.

[29] R. Parameswaran and A. Yaprak "A cross-national comparisonof consumer research measures," Journal of International Business Studies, vol. 18, 1987, pp.35-49.

[30] I.M. Martin and S. Eroglu "Measuring a multi-dimensional construct: country image,” Journal of Business Research, vol. 28, 1993, pp. 191210
[31] S. Agarwal and S. Sikri "Country image: consumer evaluation of product category extension," International Marketing Review, vol. 13 (4), pp. 44-55.

[32] I.A. Kleppe, N.M. Iversen and I.G. Stensaker "Country images in marketing strategies: conceptual issues and an empirical Asian illustration," Journal of Brand Management, vol. 10 (1), 2002, pp. 61-74.

[33] T.J. Brown, P.A. Dacin, M.G. Pratt and D.A. Whetten "Identity, intended image, construed image, and reputation: an interdisciplinary framework and suggested terminology," Journal of the Academy of Marketing Science, vol. 34 (2), 2006, pp. 99-106.

[34] B.D. Keillor, G.T.M. Hult, R.C. Erffmeyer and E. Babakus "NATID: the development and application of a national identity measure for use in international marketing," Journal of International Marketing, vol. 4 (2), 1996, pp. 57-73.

[35] B.D. Keillor, and G.T.M Hult "A five country study of national identity: implications for international marketing research and practice," International Marketing Review, vol. 16 (1), 1999, pp. 65-84.

[36] S. Anholt, Competitive Identity: The New Brand Management for Nations, Cities and Regions, Basingstoke: Palgrave Macmillan, 2007.

[37] S.K. Rainisto, Kaupungin kehittäminen merkkituotteena. Lahden ja Helsingin tapaustutkimukset. (City Branding - Case studies Lahti and Helsinki.) Licenciate thesis, Helsinki University of Technology, Espoo, 2001.

[38] J.N. Kapferer, Strategic Brand Management: Creating and Sustaining Brand Equity Long Term, 2nd ed. London: Kogan Page, 1998.

[39] D. Aaker and E. Joachimsthaler, Brand Leadership. New York: The Free Press, 2000, pp. 13, 27, 40, 48.

[40] M. Barke, and K. Harrop "Selling the industrial town: identity, image and illusion," in Place Promotion: The Use of Publicity and Marketing to Sell Towns and Regions, J.R. Gold and S.V. Ward Eds. Chichester: Wiley, 1994, pp. 93-114.

[41] S. Millington, C. Young and J. Lever "A bibliography of city marketing," Journal of Regional and Local Studies, vol. 17 (2), 1997, pp.16-42.

[42] J.R. Short and Y. Kim "Urban crises/urban representations: selling the city in difficult times," in The Entrepreneurial City: Geographies of Politics, Regimes and Representations. T. Hall and P. Hubbard, Eds. Chichester: Wiley, 1998, pp. 55-75.

[43] M. Konecnik and F.M. Go "Tourism destination brand identity: the case of Slovenia," Brand Management 15 (3), 2008, pp. 177-189.

[44] S.van Gelder, and H. Roberts "Branding brings a place to life. Planning in London 16 (63), 2007, pp. 40-42 http://www.placebrands.net/files/Branding_brings_a_place_to_life.pdf. Accessed 10 October 2012

[45] J.P. Houghton and A.Stevens "City branding and stakeholder engagement," in City Branding: Theory and Cases. K. Dinnie Ed. Basingstoke: Palgrave-Macmillan, 2011, pp. 45-53.

[46] M. Kavaratzis "From City Marketing to City Branding: Towards a Theoretical Framework for Developing City Brands," Journal of Place Branding, vol. 1(1), 2004, pp. 58-73.

[47] D. Massey "Power-geometry and a progressive sense of place," in Mapping the Futures: Local Cultures, Global Change. J. Bird, Ed. London: Routledge, 1993.

[48] J. Howe "Crowdsourcing. A definition," Retrieved November 30, 2009 from

http://www.crowdsourcing.typepad.com/cs/2006/06/crowdsourcinga.htm 1. 2006 .

[49] L.B. Erickson, I. Petrick and E.M. Trauth "Hanging with the right crowd Matching croudsourcing need to crowd characteristics," Proceedings of the Eighteenth Americas Conference on Information Systems. Seattle, Washington August 9-12, 2012. http://strategic-technologyroadmapping.com/wp-content/uploads/2013/03/Erickson-et-al-Hangingwith-the-right-crowd-AMCIS-2012.pdf. Accessed 1.10.2013

[50] Z. Servideo “Crowd branding," Pragmatic Marketer.com, winter, 2013, pp. 33-35.

[51] D.H. Meadows, D.I. Meadows, J. Randers and W. B. Behrens III, The Limits to Growth. New York: Universe Books, 1972.

[52] E. Masini, Why Futures Studies? London: Grey Seal Books. Second printing, 1994.

[53] J.C. Glenn, T.J. Gordon and E. Florescu, The Millennium Project. The 2011State of the Future. Washington, D.C, 2011. 